\title{
Avulsion fracture of the anterior inferior iliac spine in an uncommon way: A rare case
}

\author{
Ön-alt iliak çıkıntının alışılmadık şekildeki kopma kırığı: Nadir bir olgu
}

\author{
Burak Kaymaz, Mehmet Eroğlu
}

Mardin State Hospital, Orthopedics Clinics, Mardin, Turkey

\begin{abstract}
Apophyseal anterior inferior iliac spine fractures are rare injuries. They most commonly occur in athletes in adolescence period. Because the ossification of pelvis is not completed, apophyses are the weakest part of musculotendinous unit during this period, thus avulsion fractures are more frequent than muscle ruptures. The fracture occurs as a result of the pull of the straight head of the rectus femoris muscle. Patients feel a severe pain localized in groin, and cannot bear weight. With conservative treatment including bed rest, analgesia, using crutches and toe-touch weight bearing, progressing to full weight bearing as tolerated, satisfactory results could be obtained. We present a 14-year old boy with anterior inferior iliac spine fracture occurred in an uncommon manner. $J$ Clin Exp Invest 2012; 3(2): 267-269
\end{abstract}

Key words: Bone fractures, adolescent, ilium

\section{INTRODUCTION}

Apophyseal pelvic avulsion fractures are rare injuries. But, they are most commonly seen in adolescent athletes. Ossification of pelvic apophyses occurs during adolescence, in this period young people participate in a great amount of athletic activities. During sportive activities sudden contraction of the muscles attached to the spines of the pelvis can result in avulsion fractures. ${ }^{1-3}$

In the literature several cases of anterior inferior iliac spine (AIIS) and anterior superior iliac spine (ASIS) avulsion fractures have been reported. Nearly all of these patients were young and their fractures were related to sports activities. ${ }^{1}$ We report a case which occurred while falling on the floor by slipping.

\section{CASE REPORT}

A 14-year-old boy presented to the hospital with moderate pain localized in his right groin. The patient told that the pain had begun suddenly one

\section{ÖZET}

Apofizyal spina iliaka anterior inferior kırıkları nadir yaralanmalardır. Bu yaralanmalar en çok adölesan dönemdeki sporcularda meydana gelir. Pelvisin ossifikasyonu tamamlanmadığından apofizler bu dönemde muskulotendinöz birimin en zayıf parçalarıdır, bu nedenle avülzyon kırıkları kas rüptürlerinden daha sık görülür. Kırık rektus femoris kasının düz başının çekmesi sonucu oluşur. Hastalar kasık bölgesinde şiddetli bir ağrı hissederler ve yürüyemezler. Yatak istirahati, analjezi, koltuk değneği kullanımı ile başlanarak parmak ucunda yürüme ve tolere edilebildiği ölçüde tam yük vererek yürümeye kadar uzanan konservatif tedavi yöntemleri ile iyi sonuçlar elde edilebilmektedir. Yazımızda 14 yaşındaki erkek hastada nadir görülen bir yolla oluşmuş spina iliaka anterior inferior kırığını sunmayı amaçladık.

Anahtar kelimeler: Kemik kırıkları, ergen, iliak kemik

week earlier when he fell down by slipping. At that time he was unable to continue walking. Later he had persistent pain in his groin, which was aggravated by flexion of the hip. Inspection revealed no pathological findings in the inguinal region. There was tenderness on palpation in groin. Active range of motion (ROM) of the right hip was limited to $10^{\circ}$ of extension from neutral and $60^{\circ}$ of flexion.

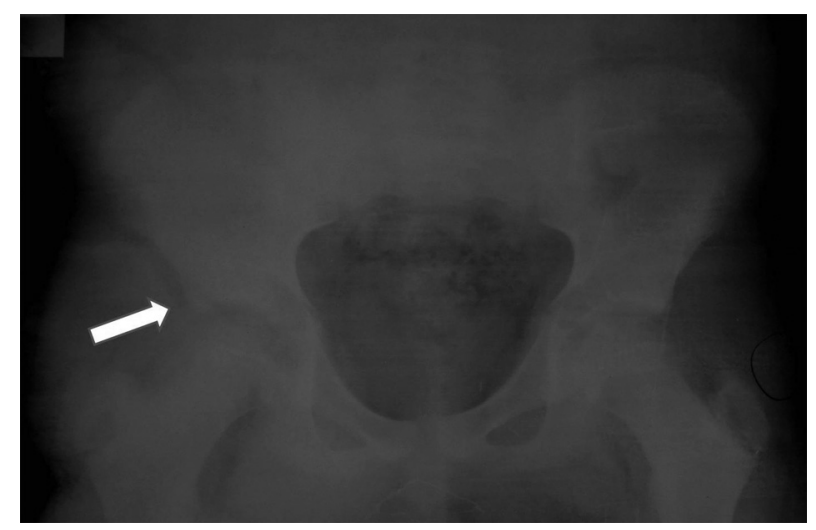

Figure1. White arrow reveals the fracture fragment.

Correspondence: Dr. Burak Kaymaz

Mardin State Hospital, Orthopedics Clinics, Mardin, Turkey Email: kaymaz23@yahoo.com

Received: 01.03.2012, Accepted: 12.03.2012

Copyright (C) JCEI / Journal of Clinical and Experimental Investigations 2012, All rights reserved 
Passive ROM was $20^{\circ}$ of extension and full flexion but painful at the end of the ROM. A plain AP radiograph (Figure 1 ) and MRI (Figure 2 ) of the pelvis revealed a bone fragment displaced inferiorly about $2 \mathrm{~cm}$ from the right anterior inferior iliac spine. Initial management consisted of a nonsteroidal antiinflammatory drug (ibuprofen) and limited weight bearing with crutches. Passive-assisted ROM exercises were started as soon as pain was tolerated. Two weeks after the patient's initial exam, he was able to walk without crutches with minimal pain. At fourth week he had normal range of motion with no pain. At his 10-week follow-up visit he had regained full strength in his hip flexors.

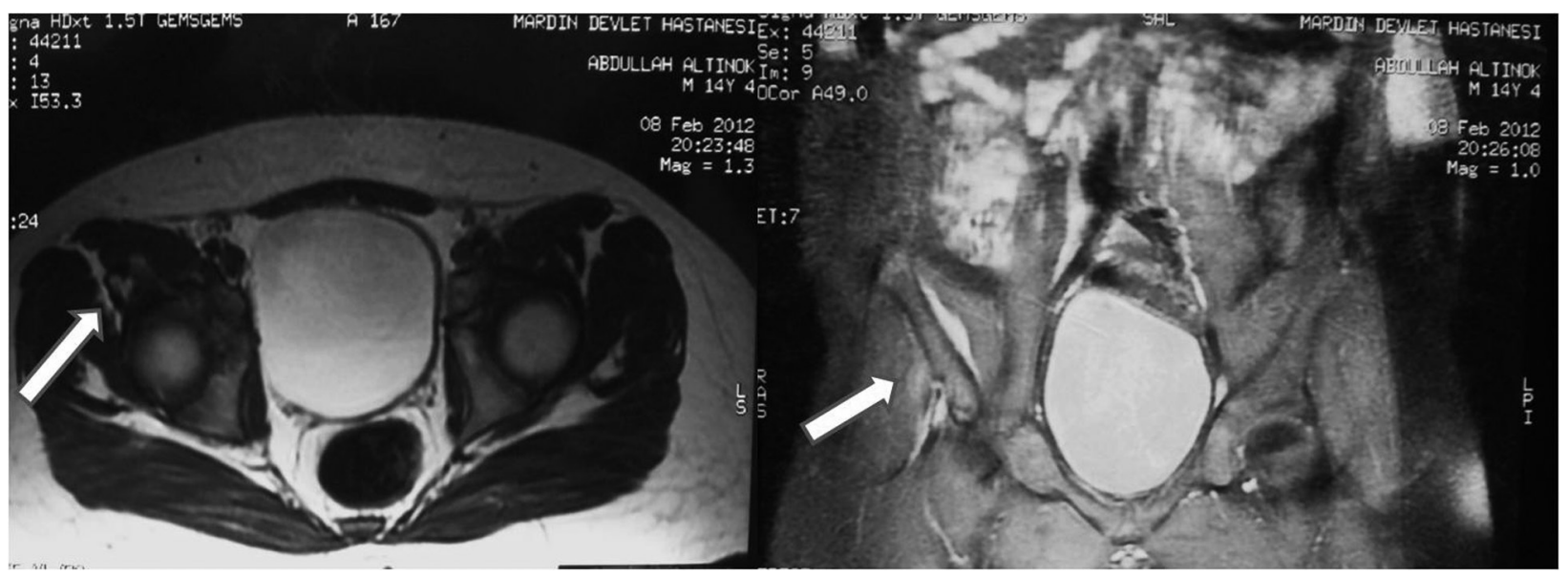

Figure 2. White arrows reveal the fracture hematoma and fragment.

\section{DISCUSSION}

Secondary ossification centers are located on the ends of long bones. Avulsion fractures are more common during early adolescence because in this period the ratio of muscular strength to physeal strength is greatest and chondrocalcinosis is not yet finished ${ }^{1}$ and during this period apophyses are the weakest part of musculotendinous unit, thus avulsion fractures are more frequent than muscle ruptures. ${ }^{3}$ In the literature the period between 13 and 17 years of age is reported to be risky for apophyseal avulsion fractures of the pelvis. ${ }^{4}$ Our patient was a 14-year-old skeletally immature boy who was injured by slipping.

Apophyseal fractures occur as a result of trauma or overuse. The most common mechanism of injury is the avulsion of apophysis from pelvis as a result of sudden concentric or eccentric contraction. However sometimes direct trauma may also cause this injury. ${ }^{3}$ Avulsion fractures of the anterior inferior iliac spine are caused by the pull of the straight head of the rectus femoris muscle. ${ }^{1,3}$ Because the rectus femoris functions as a diarthroidal muscle which extends the knee and flexes the hip joint, ${ }^{5}$ these injuries are usually related to hip hyperextension and knee flexion, which produce maximum stress on the rectus femoris tendon, as in kicking a ball. ${ }^{5}$ The most commonly cited etiologies include sprinting in track or other sports, jumping over hurdles, and kicking a soccer ball. ${ }^{6}$ In our patient the injury occurred while slipping and falling on the floor. The injury should be related to the position of the leg (i.e,hip extension and knee flexion) when the trauma occurred.

With an acute avulsion fracture of the pelvis, the patient typically reports having heard a "pop" or "snap" during physical activity and sudden, severe pain. Swelling can be noted. Local tenderness can be found by palpation. Tenderness can be detected through passive movements of the limb. Physical findings, symptoms, the patient's age and biomechanical analysis of the accident can collectively raise the suspicion of an avulsion fracture, and radiographs can confirm the diagnosis. ${ }^{1,3}$ The patient in this report presented with pain due to slipping one week before, and as he was a teenager we thought it would be an avulsion fracture. An X-ray of the pelvis revealed the fracture. We also had an MRI to assure that the fragment was displaced from AlIS.

The patient cannot bear weight because of severe pain. A mass representing the avulsed fragment may be palpated, and patient feels pain during the palpation. Although the patient is able to walk, any active flexion of the hip, as in climbing stairs, and especially against resistance, causes severe pain. ${ }^{1}$ 
The radiological appearance of AllS fracture is characteristic. The avulsed fragment is typically crescent-shaped but can also appear triangular. The fragment is usually minimally displaced inferiorly. ${ }^{1,2}$ Generally, displacement of the fragment in pelvic avulsions is no more than $1.5 \mathrm{~cm}$, and hence most avulsions can be managed non-operatively. ${ }^{7}$ In our case the fragment was located approximately $2 \mathrm{~cm}$ below the AlIS. Treatment for AlIS avulsion fracture is usually conservative, with crutches and toe-touch weight bearing, progressing to full weight bearing as tolerated. Conservative treatment consisting of bed rest, analgesia, and a five stage progressive rehabilitation program with satisfactory results was defined by Yildiz et al. In acute clinical setting there are reports of open reduction and internal fixation in the literature, but no important clinical improvements were detected and even some complications could be seen. ${ }^{6,8}$ Open reduction and internal fixation can be performed for displacements of more than $3 \mathrm{~cm}$ or in patients requiring a short reconvalescence period. 2,3 The time to full recovery may vary from 3 weeks to 4 months. ${ }^{1,5}$ With a nonsteroidal antiinflammatory drug treatment (ibuprofen) and limited weight-bearing, our patient was able to walk with minimal pain and no crutches after two weeks. At the fourth week he had no pain at full range of motion.

Return to full activity in this injury is complete with no restrictions or long term sequelae with both conservative and surgical treatment methods. ${ }^{5}$

The majority of common avulsion fractures heal adequately with conservative treatment and without complications, as was the case in the patient reported here. Surgical treatment should be kept for high demand athletes or complications and nonunions.

\section{REFERENCES}

1. Atalar H, Kayaoglu E, Yavuz OY, Selek H, Uras I. Avulsion fracture of the anterior inferior iliac spine. Ulusal Travma ve Acil Cerrahi Dergisi 2007;13(4):322-5.

2. Pointinger $H$, Munk P, Poeschl GP. Avulsion fracture of the anterior superior iliac spine following apophysitis. British journal of sports medicine. 2003;37(4):361-2.

3. Soyuncu Y, Gur S. [Avulsion injuries of the pelvis in adolescents]. Acta Orthopaedica Et Traumatologica Turcica 2004;38 Suppl 1:88-92.

4. Reina N, Accadbled F, de Gauzy JS. Anterior inferior iliac spine avulsion fracture: a case report in soccer playing adolescent twins. J Pediatric Orthopaedics Part B 2010;19(2):158-60.

5. Rajasekhar C, Kumar KS, Bhamra MS. Avulsion fractures of the anterior inferior iliac spine: the case for surgical intervention. Int Orthopaedics 2001;24(6):364-5.

6. White KK, Williams SK, Mubarak SJ. Definition of two types of anterior superior iliac spine avulsion fractures. J Pediatric Orthopaedics 2002;22(5):578-82.

7. Yildiz C, Yildiz Y, Ozdemir MT, Green D, Aydin T. Sequential avulsion of the anterior inferior iliac spine in an adolescent long jumper. Brit J Sport Med 2005;39(7):e31.

8. Milankov MZ, Harhaji V, Gojkovic Z, Drapsin M. Heterotopic ossification following surgical treatment of avulsion fracture of the anterior inferior iliac spine. Medicinski Pregled 2011;64(11-12):593-6. 